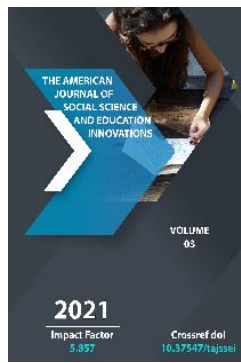

\title{
The Heritage Of Our Great Ancestors And The Third
}

\section{Renessans}

\author{
Pardaeva Marhabo Davlatovna \\ Candidate Of Philosophical Sciences, Associate Professor, Independent Researcher of \\ Bukhara State University, Bukhara, Uzbekistan
}

\begin{abstract}
Journal Website:
https://theamericanjou

rnals.com/index.php/ta

jssei

Copyright: Original content from this work may be used under the terms of the creative commons attributes 4.0 licence.
\end{abstract}

\section{ABSTRACT}

The article analyzes important aspects of the systematic organization of spiritual and educational work in our country. The Renaissance, which took place in the history of mankind, revealed the peculiarities of the development of science. The idea of a perfect man in the works of Alisher Navoi has been studied historically and philosophically. The importance of the idea of a perfect man in the creative heritage of the thinker in the upbringing of a harmoniously developed generation in the new conditions of Uzbekistan is highlighted.

\section{KEYWORDS}

Perfect man, science, ancestral heritage, Renaissance, humanism.

\section{INTRODUCTION}

The fate and future of any society, of the people who live in it, is, of course, closely linked with the upbringing of young people, who are the leading forces of the state. From time immemorial, the great Uzbek people have paid special attention to the education of children and youth. After all, the future of our country depends on our young generation, who have confidence in the future. In the current process of globalization, the fight against ignorance and enlightenment is very important. It should be noted that the systematic organization of spiritual and educational work in our country, increasing the effectiveness of measures taken in this direction, raising the intellectual potential, consciousness and worldview of the population, especially youth, strengthening ideological immunity, patriotism, love and devotion to the people. special attention is paid to upbringing. The announcement of 2021 
as the "Year of comprehensive support of youth and public health" is clear evidence of the attention paid to youth in our country.

\section{MATERIALS AND METHODS}

At different times, in different forms, humanity has experienced a period of awakening and ascension, a phenomenon that scientists call the "renaissance". The Renaissance, a very rare event in the history of all mankind, occurs in the West and East only two or three times a thousand years. IX-XII centuries - the Renaissance was the first renaissance in the history of the peoples of Turan, while the second Renaissance in the life of our ancestors, associated with the activities of Amir Temur, Mirzo Ulugbek, Alisher Navoi, Mirzo Babur, remained in history forever. The laws, decrees and resolutions signed by the head of our state Sh. Mirziyoyev for the development of enlightenment, education and science in recent years, as well as his noble initiatives lay a solid foundation for a new Enlightenment in Uzbekistan [1-3]. Of course, this is the result of a focus on science and enlightenment. It should be noted that the development of science is based on the ideas, works and teachings created by our ancestors. It is known from history that in both Renaissance periods created by our ancestors, world science was a great impetus to us. The Mamun Academy, founded in Khorezm during the first Renaissance, which defined the principles of the rise of world development, brought together great thinkers and mastered the most advanced sciences of the world, which serve as a model for the whole world. The schools of science created by the Timurids followed the same path. During this period, too, people began to flock from all over the world to learn science.

Today, the idea of the third Renaissance, known to the world as the new Uzbekistan, can unite the state, society and the whole nation around it. The issue of man and his upbringing, the development of a mature person has long been in the focus of attention of Eastern scientists, thinkers and sages. They elevated the human race to the heights they considered the best of all living beings. The Renaissances that took place during historical development were based on these great ideas. Hence, the Renaissance is characterized by the elevation of man and his qualities. In the views of Alisher Navoi, the sultan of the realm of words, humanity plays a key role. As a great sage and humanist of this period, Hazrat Navoi, like his predecessors, glorified the human race. According to him, man differs from other beings in the world by his language, mind, and power of thought.

In his works, Hazrat Navoi pays attention to humanity, various aspects of humanity, which serve as the basis for a perfect man. According to the thinker, in order to do good to others, to do good deeds and righteous deeds, to be engaged in good deeds, one must first be patient, contented, self-controlled, in other words, educated oneself. Only then will he appreciate others and care more about them. The thinker says that a person should first of all be patient, content, and be content with a loaf of bread earned by his honest labour. An important feature of Navoi's humanistic views here is that when the scholar speaks of human qualities such as patience, kindness, generosity, charity, helping the needy, he sees them as interdependent, as complementary, close concepts in content. considered. In Mahbub ul-Qulub, the thinker describes contentment as an integral part of humanity and argues that greed is an inhuman vice. "Satisfaction," says the scholar, "is the basis of shyness, the celebration of honour and dignity." The contented poor are the rich, and the beggar has nothing to do with the king. Evidence of greed; the state is greedy and despised.

Whoever can get it with greed, but does not get it, greed will never be deprived of generosity. These kinds of generous people do 
good deeds, and greedy people crawl in disgust" [5].

Patience, like contentment, is an important human quality. Giving in to lust can only be overcome through patience. On the contrary, impatience leads man to evil ways, patience repels all calamities. "Patience is bitter, but the one who benefits is hard - but one who repels harm" [6].

\section{RESULTS}

Thus, Navoi considers patience as the beauty of humanity. The notion of contentment, in his worldview, means living by one's own labour, not looking at other people's property, not being greedy and greedy, living contentedly with one's earnings, and helping others if possible. From this point of view, the thinker's thoughts on generosity are in harmony with his views on patience. In general, scholars who have studied Alisher Navoi's worldview acknowledge that he has made a comprehensive, in-depth analysis of his concept of generosity, looking at its various aspects. Indeed, Navoi considers generosity as an important attribute of humanity, perfection. Humanity is a rare quality that makes man human, distinguishing him from other living beings. Generosity is an integral part of humanity. Alisher Navoi called on people to show kindness to people, to do good deeds, to restrain lust, to give to the poor, to be compassionate and compassionate, to always take care of the people, to live in their worries, puts humanity and humanity above all:

Odamiy ersang demagil odami,

Oniki yo‘q xalq g'amidin g'ami [7].

It is obvious that the thinker puts above all such qualities as humanity, humanity, loyalty, kindness, living in the care of the people, even sacrificing his life for the sake of its well-being, happiness, charity, generosity to others. In this way, Navoi glorifies man, his qualities, convincingly proves that he is superior to other creatures. According to the thinker, there are people in life who, even if they look human on the outside, their deeds and behaviour are not human. Their words and deeds are different, and what they do is nothing but ugliness and hypocrisy. Hazrat Navoi understands cabbage and charity in a very broad sense. According to the thinker, cabbage means to ease someone's heavy burden, a difficult life. But a person should not be grateful for the good he has done, his help, and should not forget it. Ihsan, on the other hand, is the basis of humanity, a set of all human qualities, beautiful qualities and abilities, "it contains all goodness, and all goodness really belongs to it" [8-12].

In short, in Navoi's worldview, cabbage, charity, kindness, humility, humility, selfcontrol, good deeds, manners, righteous deeds are interpreted as interrelated concepts, complement each other, one of them is inseparable from the other. All of these moral values come together to form humanity. They serve as an important basis in educating a person to be a perfect person, to grow up happy and prosperous. Another important feature of Navoi's humanity, in our opinion, is that he not only expressed his views and valuable ideas on humanism in his ghazals, rubais and epics but also earned the title of a great humanist poet, an example to others in humanity. He has always shared in the worries of the common people, sponsored them. Hazrat Navoi personally carried out large-scale beautification works from his own income. It is known from history that he built more than 300 rabats, baths and khanaqahs, pools, madrasas and mosques in Khorasan, built irrigation facilities and dug canals. Khandamir lists some of them in his book. Therefore, Mir Alisher's treasury never accumulated large sums of money. The proceeds were quickly distributed to the needy or used to build buildings. 


\section{CONCLUSION}

The ideas of humanity are also reflected in the epics of Hazrat Navoi, which are included in "Khamsa". In his epics "Layli and Majnun", "Farhod and Shirin", "Saddi Iskandariy" and others, the symbols of Alexander, Farhod, Shirin, Socrates, Plato, Layli, Majnun are described not as historical figures, but as artistic symbols. They embody high moral qualities, noble values, humanity. These images are narrated in accordance with the socio-philosophical, moral and humanistic views of the scholar. As a result of studying and analyzing the idea of the perfect man in the works of the thinker, the following conclusions were drawn:

1. Alisher Navoi's views on the perfect man play an important role in educating the youth of our society as a harmoniously developed generation, in understanding its essence.

2. Analysis of the works of Alisher Navoi shows that a perfect man is a just, wise, wise, noble, courageous man, who embodies such human qualities as patriotism, nationalism, humanism, justice, tolerance, bravery, diligence, sweetness, loyalty, patience.

3. The qualities of patriotism, humanism, and nationalism put forward in the works of the thinker mean that he approached the idea of the perfect man from the point of view of the harmony of nationality and humanity.

4. The idea of the perfect man in the Middle Ages played an important role not only in education, in leading people to perfection, but also in the development of countries and the rise of the spirituality of peoples. The immortal works of the great scholar, which express the idea of a perfect man, have in recent times played a great role in the humanization of the people of Movarounnahr and Khorasan, in inculcating universal values in their way of life and consciousness.
5. In the works, immortal epics, ghazals and rubais of Alisher Navoi, he not only expressed the views and valuable ideas about the perfect man but also earned the title of a great humanist poet, an example to others in humanity. He has always shared in the worries of the common people, sponsored them. These circumstances show that Alisher Navoi had a practical approach to the idea of a perfect man. If we call this great person a saint, he is a saint of saints, a thinker, a thinker of thinkers, a poet, a sultan of poets. Indeed, the immortal ideas of the great poet about the perfect man, his wise thoughts are an important basis for the rise of our society, the education of young people as harmoniously developed people. The idea of a perfect man is a priority idea and principle of New Uzbekistan and plays an important role in improving the national idea.

6. In the current situation, the use of the national spiritual heritage left by our ancestors, the observance of the teachings of the older generation is of great importance in raising the spirituality of our youth, educating them. Such great goals are embodied in today's great ideas, which serve as a solid foundation for the Third Renaissance.

\section{REFERENCES}

1. Resolution of the President of the Republic of Uzbekistan No. PF-6017 of 30.06.2020 "On measures to radically reform the state youth policy in the Republic of Uzbekistan and bring it to a new level".

2. Resolution of the Cabinet of Ministers of the Republic of Uzbekistan No. 23 of 18.01.2021 "On approval of the Concept of development of state youth policy in Uzbekistan until 2025".

3. Address of the President of the Republic of Uzbekistan to the Oliy Majlis of December 29, 2020. 
4. Alisher Navoi. (1998). Mahbub ulqulub. MAT. T.14. Tashkent: Fan. B. 103.

5. Karimov I.A. (2008). High spirituality is an invincible force. Tashkent: Spirituality. B. 47.

6. Alisher Navoi. (1991). Hayratul-abror. MAT. T.7. Tashkent: Fan. B. 240.

7. Kenjaeva, X. (2021). Educational issues in our national spiritual heritage. Society and Innovation, 2 (6 / S), 18-24.

8. Pardaeva, M. D. (2021). The place of the views of Hazrat Alisher Navoi in the spirituality of the people with a glorious past and a great future. Innovations in pedagogy and psychology, 4 (3).

9. Pardaeva, M. D. (2020). The role of the jadid's thinking views in the fight against enlightenment against ignorance. Ўтмишга назар журнали, 10(3).

10. Пардаева, М. А., Узбекистан, Р., \& Голди-Скотт, М. Р. (2020). Реформа школьного образования в Узбекистане: переосмысление методики обучения и оценки. ISBN 978-5-9929-0917-3॰ ОГУ имени ИС Тургенева, 2020๔ МОО «Академия информатизации образования», 2020॰ Коллектив авторов, 2020, 25.

11. Пардаева, М. А. (2018). Использование средств народной педагогики в воспитании толерантности у молодежи. Проблемы педагогики, (6 (38)).

12. Djuraeva, D. D., \& Berdiyeva, Z. M. (2016). Cultural heritage as a factor of human development (on the example of Uzbekistan). Ученый XXI века, 23. 